\title{
The influence of sodium propionate on blood glucose, insulin and cortisol concentrations in calves of different ages
}

\author{
Biljana Radojičić ${ }^{1}$, Mirjana Joksimović-Todorović ${ }^{2}$, Maja Bukvić ${ }^{1}$, Predrag Simeunović ${ }^{1}$ \\ Murat Kakishev ${ }^{3}$, Nermin Pračić ${ }^{4}$

\begin{abstract}
${ }^{1}$ University of Belgrade, Faculty of Veterinary Medicine, Department of Ruminants and Swine Disease, Belgrade, ${ }^{2}$ Faculty of Agriculture, Department of Nutrition, Belgrade-Zemun, Serbia

${ }^{3}$ West Kazakhstan Agrarian Technical University named after Zhangir Khan, Uralsk, Kazakhstan ${ }^{4}$ University of Bihać, Biotechnical Faculty, Bihać, Bosnia and Herzegovina
\end{abstract}

Received October 26, 2015

Accepted May 2, 2016

\begin{abstract}
The process of gluconeogenesis in ruminants is under the direct influence of insulin and glucocorticoid hormones. The goal of this study was to determine the effects of added Napropionate on the neuroendocrine regulation of blood glucose in calves at three specific physiological periods: on exclusive milk nutrition; on mixed milk and forage nutrition; and with established ruminant digestion. The influence of Na-propionate on blood glucose, insulin and cortisol concentrations was examined in the same 20 female Holstein calves at different stages of forestomach development (15 days, 2 months, and 4 months of age of calves). Group 1 of calves $(n=10)$ received Na-propionate intravenously; group $2(n=10)$ received Na-propionate mixed in milk. Blood sampling was performed 1 and $3 \mathrm{~h}$ after Na-propionate administration. After i.v. administration of Na-propionate, a significant increase $(P<0.05)$ in blood glucose concentration was observed $1 \mathrm{~h}$ after administration only in calves aged 2 and 4 months; blood insulin concentration was significantly higher $(P<0.01) 1$ and $3 \mathrm{~h}$ after i.v. administration in 2 -month-old calves; and cortisol concentration increased $(P<0.01) 1 \mathrm{~h}$ after administration in each selected calf in all testing periods. Orally administered Na-propionate led to a significant increase $(P<0.01)$ of insulin concentration 1 and $3 \mathrm{~h}$ after administration in 15-day-old calves, and $3 \mathrm{~h}$ after administration in 2-month-old calves. Based on these results it could be assumed that i.v. and p.o. administration of Na-propionate affects the neuroendocrine regulation of glycaemia in calves of different age.
\end{abstract}

\section{Cattle, Na-propionate, neuroendocrine regulation, gluconeogenesis}

In ruminants, most glucose is supplied by gluconeogenesis, and homeostasis of glucose is considered to be an essential factor of the metabolic status affecting the performance of dairy calves. It is a well-known fact that gluconeogenesis in ruminants is under the direct influence of glucocorticoid hormones. Significant rise in cortisol concentration with subsequent dose-depended increase of glucose and insulin contents were recorded shortly after i.v. administration of propionate to dairy cows (Bradford et al. 2006). Gluconeogenesis in suckling (pre-ruminating) calves shows many similarities to that in monogastric species (Leat 1970). As the weaning period approaches, phylogenetic features of carbohydrate metabolism that prepare them for later life (e.g., a high capacity for gluconeogenesis from propionate and a relatively low suppressive action of insulin on gluconeogenesis) are much more expressed (Hostettler-Allen et al. 1994; Donkin and Armentano 1995). After they start to ingest fibre carbohydrates from feed, propionate stimulates glucose synthesis and insulin assumes the primary role in the neuroendocrine regulation of glycaemia (Radojicic et al. 2007).

Propionate is the most abundant (15-40\% of total ruminally released organic acids) and by far the most substantial substrate for gluconeogenesis in ruminants (Reynolds et al. 1998; Overton et al. 2004; Larsen and Kristensen 2009). In terms of the hepatic uptake, propionate

Address for correspondence:

Dr. Biljana Radojičić, Ph.D.

Department of Ruminants and Swine Disease

Faculty of Veterinary Medicine, University of Belgrade

Bulevar oslobodjenja 18,11000, Belgrade, Serbia

Phone: +381113615436

E-mail: biljanar@vet.bg.ac.rs

http://actavet.vfu.cz/ 
is quantitatively the most important source of $\mathrm{C} 3$ carbon $(60-74 \%)$ for hepatic gluconeogenesis. Intraruminal infusion of propionate after a meal in cows increased intracellular energy status with no adverse effect on the capacity of gluconeogenesis in the liver (Oba and Allen 2003). Johnson et al. (1982) examined the effect of glucose and propionate administered orally on the concentration of insulin in calves aged up to 38 days. The strongest effect of propionate administration was manifested in newborn calves where high concentrations of insulin were maintained significantly longer compared to those recorded in 7- and 14-day-old calves. Djokovic et al. (2007) examined the influence of propionate as a dietary energy source in prevention of ketosis in dairy cows, and its role in the metabolism of some hormones. Gorka et al. (2009) concluded that dietary supplementation of sodium butyrate had a positive influence on rumen development and health status of newborn calves in the first weeks of life. It induces better health and animal performances around the weaning period. Supplementation of sodium butyrate seems to have both direct and indirect effects on the development of forestomach, abomasum and small intestine. Nazari et al. (2012) examined the impact of calcium butyrate in the milk replacer on the concentration of glucose, insulin and cortisol in calves aged 1, 12, 24,36 , and 48 days. The authors found that there was a significant increase in blood glucose and insulin concentrations, and a decrease of cortisol concentrations in all experimental periods, except the first day.

The aim of this study was to determine the effect of exogenously added Na-propionate on the neuroendocrine regulation of blood glucose in calves at three specific physiological periods: on exclusive milk nutrition (15 days old); mixed milk and forage nutrition (2 months old); and with established ruminant digestion (4 months old).

\section{Materials and Methods}

\section{Experimental animals}

The influence of exogenous Na-propionate on blood glucose, insulin and cortisol concentrations was examined in the same 20 female Holstein calves at the different stages of forestomach development (15 days, 2 months and 4 months of age of calves). When the selected calves were 15 days old, they were fed solely milk diet in two equal rations. Two-month-old calves were beside dairy meal also fed roughage and concentrate ad libitum. Calves aged 4 months were given only bulky and concentrated feed ad libitum.

Na-propionate loading test

Na-propionate loading test was performed at three time periods: when the calves were aged 15 days, 2 months, and 4 months. Prior to testing, selected calves $(n=20)$ were divided into two equal groups. Group 1 of calves $(\mathrm{n}=10)$ was intravenously (i.v.) administered a sterile solution of 1.84 molar Na-propionate at the dose of $1 \mathrm{ml}$ per kg body weight. Group 2 of calves $(\mathrm{n}=10)$ received Na-propionate per os (p.o.) mixed in milk $(5 \mathrm{~g} / \mathrm{calf})$. The Na-propionate loading test was repeated in the same groups of calves in an identical manner when the calves were 2 and 4 months old. All tests were performed always at the same time of day, around 10:00 h.

Blood sampling and determination of glucose, insulin and cortical levels

Blood samples were taken by puncture of vena jugularis prior, 1 , and $3 \mathrm{~h}$ after the administration of Napropionate. Blood glucose concentration was determined using commercial test strips (Precision Xceed ${ }^{\circledR}$, Abbott, USA). Cortisol and insulin concentrations in blood serum were determined using specific radioimmunoassay (RIA kit) Cortisol-RIA kit and Insulin-RIA kit as per instructions of the producer, th Institute for the Application of Nuclear Energy (INEP, Belgrade-Zemun, Serbia).

Statistical analysis

Variables used for descriptive statistics were the following: arithmetic mean, standard deviation, standard error, variation interval, and coefficient of variation. In order to test significant differences between investigated treatments multifactorial ANOVA was used. For individual comparisons of significant differences Tukey test was used. Data analyses were performed using PASW Statistics 18 and MS Excel.

\section{Results}

The baseline values for blood glucose concentration were the highest in calves aged 15 days and the lowest in 4-month-old calves (Table 1). After i.v. application of Na- 
propionate, a significant increase $(P<0.05)$ in blood glucose concentration was observed only in calves aged 2 and 4 months, $1 \mathrm{~h}$ after administration.

Table 1. Concentration of blood glucose $(\mathrm{mmol} / \mathrm{l})$ of calves at various ages, before and after administration Napropionate, given i.v. and p.o.

\begin{tabular}{|c|c|c|c|c|c|}
\hline \multirow{2}{*}{$\begin{array}{l}\text { Time of } \\
\text { investigation }\end{array}$} & \multirow{2}{*}{$\begin{array}{l}\text { Administration } \\
\text { method }\end{array}$} & \multirow{2}{*}{$\begin{array}{l}\text { Statistical } \\
\text { variables }\end{array}$} & \multicolumn{3}{|c|}{ Age of investigated calves } \\
\hline & & & 15 days & 2 months & 4 months \\
\hline $\mathrm{T}_{0}$ & $\begin{array}{l}\text { Before application } \\
(\mathrm{n}=20)\end{array}$ & $\overline{\mathrm{X}} \pm \mathrm{SD}$ & $8.92 \pm 3.35$ & $8.08 \pm 1.56$ & $3.89 \pm 0.69$ \\
\hline \multirow[t]{2}{*}{$\mathrm{T}_{1}$} & $\begin{array}{l}1.84 \mathrm{~mol} \text { sterile sol. } \\
1 \mathrm{ml} / \mathrm{kg} \text { b.w. i.v. } \\
(\mathrm{n}=10)\end{array}$ & $\overline{\mathrm{X}} \pm \mathrm{SD}$ & $6.15 \pm 1.74$ & $9.59 \pm 1.59^{\mathrm{A}}$ & $6.02 \pm 2.24^{\mathrm{A}}$ \\
\hline & $\begin{array}{l}5 \mathrm{~g} \text { in powder mixed by milk, p.o. } \\
(\mathrm{n}=10)\end{array}$ & $\overline{\mathrm{X}} \pm \mathrm{SD}$ & $8.96 \pm 1.45$ & $8.01 \pm 1.77$ & $5.58 \pm 1.42$ \\
\hline \multirow[t]{2}{*}{$\mathrm{T}_{3}$} & $\begin{array}{l}1.84 \mathrm{~mol} \text { sterile sol. } \\
1 \mathrm{ml} / \mathrm{kg} \text { b.w., i.v. } \\
(\mathrm{n}=10)\end{array}$ & $\overline{\mathrm{X}} \pm \mathrm{SD}$ & $5.88 \pm 0.98$ & $7.18 \pm 2.22$ & $5.35 \pm 0.71$ \\
\hline & $\begin{array}{l}5 \mathrm{~g} \text { in powder mixed by milk, p.o. } \\
(\mathrm{n}=10)\end{array}$ & $\overline{\mathrm{X}} \pm \mathrm{SD}$ & $7.68 \pm 0.95$ & $6.63 \pm 1.29$ & $5.25 \pm 0.69$ \\
\hline
\end{tabular}

T0 - time before application, T1 - $1 \mathrm{~h}$ after application, T3 - $3 \mathrm{~h}$ after application $P<0.01(\mathrm{a}, \mathrm{b}, \mathrm{c}) ; P<0.05(\mathrm{~A}, \mathrm{~B}, \mathrm{C})$

The baseline values for insulin concentration were the highest in 2 month-old-calves (Table 2). Orally administered Na-propionate led to a significant increase $(P<0.01)$ of insulin concentration in calves aged 15 days, 1 and $3 \mathrm{~h}$ after administration.

Table 2. Concentration of blood insulin (pmol/1) of calves at various ages, before and after application Napropionate, given i.v. and p.o.

\begin{tabular}{|c|c|c|c|c|c|}
\hline \multirow{2}{*}{$\begin{array}{l}\text { Time of } \\
\text { investigation }\end{array}$} & \multirow{2}{*}{$\begin{array}{l}\text { Administration } \\
\text { method }\end{array}$} & \multirow{2}{*}{$\begin{array}{l}\text { Statistical } \\
\text { variables }\end{array}$} & \multicolumn{3}{|c|}{ Age of investigated calves } \\
\hline & & & 15 days & 2 months & 4 months \\
\hline $\mathrm{T}_{0}$ & $\begin{array}{l}\text { Before application } \\
(\mathrm{n}=20)\end{array}$ & $\overline{\mathrm{X}} \pm \mathrm{SD}$ & $148.62 \pm 55.56$ & $530.60 \pm 277.8$ & $186.12 \pm 46.53$ \\
\hline \multirow[t]{2}{*}{$\mathrm{T}_{1}$} & $\begin{array}{l}1.84 \mathrm{~mol} \text { sterile sol. } \\
1 \mathrm{ml} / \mathrm{kg} \text { b.w. i.v. } \\
(\mathrm{n}=10)\end{array}$ & $\overline{\mathrm{X}} \pm \mathrm{SD}$ & $167.37 \pm 56.95$ & $707.00 \pm 670.19^{a}$ & $177.10 \pm 27.78$ \\
\hline & $\begin{array}{l}5 \mathrm{~g} \text { in powder mixed by milk, p.o. } \\
(\mathrm{n}=10)\end{array}$ & $\overline{\mathrm{X}} \pm \mathrm{SD}$ & $856.32 \pm 697.97^{\mathrm{a}}$ & $474.34 \pm 343.78$ & $139.59 \pm 27.78$ \\
\hline \multirow[t]{2}{*}{$\mathrm{T}_{3}$} & $\begin{array}{l}1.84 \mathrm{~mol} \text { sterile sol. } \\
1 \mathrm{ml} / \mathrm{kg} \text { b.w., i.v. } \\
(\mathrm{n}=10)\end{array}$ & $\overline{\mathrm{X}} \pm \mathrm{SD}$ & $169.46 \pm 55.56$ & $781.31 \pm 558.38^{a}$ & $204.88 \pm 46.53$ \\
\hline & $\begin{array}{l}5 \mathrm{~g} \text { in powder mixed by milk, p.o. } \\
(\mathrm{n}=10)\end{array}$ & $\bar{X} \pm \mathrm{SD}$ & $827.84 \pm 586.16^{\mathrm{a}}$ & $800.06 \pm 730.6^{\mathrm{a}}$ & $148.62 \pm 46.53$ \\
\hline
\end{tabular}

T0 - time before application, T1 - $1 \mathrm{~h}$ after application, T3 - $3 \mathrm{~h}$ after application

$P<0.01(\mathrm{a}, \mathrm{b}, \mathrm{c}) ; P<0.05$ (A, B, C) 
In 2-month-old calves blood insulin concentration was significantly higher $(P<0.01) 1$ and $3 \mathrm{~h}$ after i.v. application, and also $3 \mathrm{~h}$ after oral administration (Fig. 2).

The baseline concentration of cortisol showed the lowest values in 4-month-old calves (Table 3). Following i.v. administration of Na-propionate a significant increase in the cortisol concentration $(P<0.01)$ occurred $1 \mathrm{~h}$ after application in each selected calf and in all testing periods. Except for the 4-month-old calves where cortisol concentration was significantly higher $(P<0.01)$, in all experimental calves blood cortisol returned to values near baseline $3 \mathrm{~h}$ after p.o. administration of $\mathrm{Na}$-propionate.

Table 3. Concentration of blood cortisol (nmol/l) of calves at various ages, before and after application Napropionate, given i.v. and p.o.

\begin{tabular}{|c|c|c|c|c|c|}
\hline \multirow{2}{*}{$\begin{array}{l}\text { Time of } \\
\text { investigation }\end{array}$} & \multirow{2}{*}{$\begin{array}{l}\text { Administration } \\
\text { method }\end{array}$} & \multirow{2}{*}{$\begin{array}{l}\text { Statistical } \\
\text { variables }\end{array}$} & \multicolumn{3}{|c|}{ Age of investigated calves } \\
\hline & & & 15 days & 2 months & 4 months \\
\hline $\mathrm{T}_{0}$ & $\begin{array}{l}\text { Before application } \\
(\mathrm{n}=20)\end{array}$ & $\overline{\mathrm{X}} \pm \mathrm{SD}$ & $7.7 \pm 4.1$ & $7.0 \pm 2.4$ & $5.0 \pm 2.6$ \\
\hline \multirow[t]{2}{*}{$\mathrm{T}_{1}$} & $\begin{array}{l}1.84 \mathrm{~mol} \text { sterile sol. } \\
1 \mathrm{ml} / \mathrm{kg} \text { b.w. i.v. } \\
(\mathrm{n}=10)\end{array}$ & $\overline{\mathrm{X}} \pm \mathrm{SD}$ & $17.4 \pm 16.1^{\mathrm{a}}$ & $28.8 \pm 19.8^{\mathrm{a}}$ & $14.5 \pm 13.2^{\mathrm{a}}$ \\
\hline & $\begin{array}{l}5 \mathrm{~g} \text { in powder mixed by milk, p.o. } \\
(\mathrm{n}=10)\end{array}$ & $\overline{\mathrm{X}} \pm \mathrm{SD}$ & $7.54 \pm 4.89$ & $7.21 \pm 1.83$ & $16.24 \pm 6.60^{\mathrm{a}}$ \\
\hline \multirow[t]{2}{*}{$\mathrm{T}_{3}$} & $\begin{array}{l}1.84 \mathrm{~mol} \text { sterile sol. } \\
1 \mathrm{ml} / \mathrm{kg} \text { b.w., i.v. } \\
(\mathrm{n}=10)\end{array}$ & $\overline{\mathrm{X}} \pm \mathrm{SD}$ & $9.5 \pm 7.5$ & $6.9 \pm 2.1$ & $6.8 \pm 5.0$ \\
\hline & $\begin{array}{l}5 \mathrm{~g} \text { in powder mixed by milk, p.o. } \\
(\mathrm{n}=10)\end{array}$ & $\overline{\mathrm{X}} \pm \mathrm{SD}$ & $8.48 \pm 4.14$ & $8.67 \pm 3.88$ & $19.28 \pm 12.13^{\mathrm{a}}$ \\
\hline
\end{tabular}

T0 - time before application, T1 - $1 \mathrm{~h}$ after application, T3 - $3 \mathrm{~h}$ after application $P<0.01(\mathrm{a}, \mathrm{b}, \mathrm{c}) ; P<0.05(\mathrm{~A}, \mathrm{~B}, \mathrm{C})$

\section{Discussion}

The aim of this work was to test the influence of exogenous Na-propionate on the concentrations of blood glucose and hormones responsible for glycaemic control, especially in young animals at life stages when they are not yet formed as ruminants (Gončarova 1988; Silke 1989; Radojicic et al. 2007).

Our results showed that baseline levels for blood glucose in 15-day-old, 2-month-old, and 4-month-old calves were $8.92 \pm 3.35 \mathrm{~mol} / 1 ; 8.08 \pm 1.56$ and $3.89 \pm 0.69$, respectively. These values are in accordance with results from similar investigations by Stamatović et al. (1984) and Radojičić et al. (2007). One hour after i.v. administration, Na-propionate led to a significant increment in blood glucose concentrations in 2- and 4-month-old calves. These results are in agreement with the findings of Nazari et al. (2012). Results of different studies point out the fact that non-esterified fatty acids (NEFA) in calves stimulate the insulin secretion from B cells of the endocrine pancreas, therefore, their role in glucose synthesis is fundamental (Johnson et al. 1982; Radojicic et al. 2007).

Our results showed the highest baseline levels for blood insulin in 2-month-old calves. In these calves insulin concentration increased significantly 1 and $3 \mathrm{~h}$ after i.v. and $3 \mathrm{~h}$ after p.o. administration of Na-propionate. This could be interpreted by the fact that propionate influences insulinaemia even in the suckling calves (Nikolić et al. 1996). Nazari et al. 
(2012) detected a significant rise in insulin content in calves treated orally with Ca-butyrate. The observed increase could be explained by the particularity of the NEFA effect on rumen development in calves (Hammon et al. 2002; Gorka et al. 2009).

Cortisol concentration reaches peak values in newborn calves but significantly decreases with the age (Goncarova 1988; Silke 1989; Radojicic et al. 2007; Nazari et al. 2012). Our experiment resulted in a significant increase of cortisol in calves $1 \mathrm{~h}$ after i.v. applicaton of Na-propionate in each investigated period. However, oral administration of Na-propionate resulted in a rise of blood cortisol only in 4-month-old calves, i.e. in the ontogenetic period when calves start to assume traits characteristic of ruminant digestion physiology. In contrast, Nazari et al. (2012) did not find cortisol increment after oral administration of Ca-butyrate to 1-, 12-, 24-, 36- and 48-day-old calves.

Our results showed that $1 \mathrm{~h}$ after i.v. administration Na-propionate led to: an increase of blood glucose in 2- and 4-month-old calves; an increase of insulin in 2-month-old calves; and an increase of cortisol in calves in each investigated period. After p.o. administration, Na-propionate caused an increase of insulin in 15-day-old and 2-month-old calves, and an increase of cortisol only in 4-month-old calves. This study also confirmed that Napropionate in addition to glucose is an important factor in the regulation of B-cell activity of the endocrine pancreas. Based on these results it could be assumed that i.v. and p.o. administration of Na-propionate affects the neuroendocrine regulation of glycaemia in calves of different ages.

\section{References}

Bradford BJ, Gour AD, Nash AS, Michael SA 2006: Propionate challenges tests have limited for investigation bovine metabolism. Journal Nutr 136: 1915-1920

Donkin SS and Armentano LE 1995: Insulin and glucagon regulation of gluconeogenesis in preruminating and ruminating bovine. J Anim Sci 73: 546-551

Djokovic R, Samanc H, Nikolic Z, Boskovic Bogosavljevic S 2007: Changes in blood values of glucose, insulin, and inorganic phosphorus in healthy and ketotic dairy cows after intravenous infusion of propionate solution. Acta Vet Brno 76: 533-539

Gorka P, Kowalski ZM, Pietrzak P, Kotunia A, Kiljanczyk R, Flaga J, Holst JJ, Guilloteau P, Zabielski R 2009: Effect of sodium butyrate supplementation in milk replacer and starter diet on rumen development in calves. J Physiol Pharmacol 60: 47-53

Gončarova J 1988: Nespecificni faktori na imuniteta pri teleti zavisiom ot s drzanieto na kortikosteroidni hormoni. Veterinarna Med Nauki 8: 33-36

Hammon HM, Schiessler G, Nussabaum A, Blum JW 2002: Feed intake patterns, growth performance and metabolic and endocrine traits in calves fed unlimited amounts of colostrum and milk by automate, starting in the neonatal period. J Dairy Sci 85: 3352-3362

Hostettler-Allen R, Tappy L, Blum JW 1994: Insulin resistance, hyperglycemia and glucosuria in intensively milk-fed calves. J Anim Sci 72: 160-173

Johnson DD, Mitchell Jr. GE, Tucker RE, Hemken RW 1982: Plasma glucose and insulin response to propionate in preruminating calves. J Animal Sci 55: 1224-1230

Larsen M, Kristensen NB 2009: Effect of abomasal glucose infusion on splanchnic amino acid metabolism in periparturient dairy cows. J Dairy Sci 92: 3306-3318

Leat WMF 1970: Carbohydrate and lipid metabolism in the ruminant during post-natal development. In Digestive Physiology and Metabolism in the Ruminants (Phillipson, A. T., ed.). Oriel Press, Newcastle Upon Tyne, UK, pp. 211-222

Nazari M, Karkoodi K, Alizadeh A 2012: Performance and physiological response of milk-fed calves to coated calcium butyrate supplementation. S Afr J Anim Sci 42: 296-303

Nikolić JA, Šamanc H, Damnjanović Z, Ratković M, Radojičić B, Begović J 1996: Concentrations of serum cortisol, insulin and glucagon in young calves before and after receiving propionate orally. Proc Nutr Soc 55: 98

Oba M, Allen MS 2003: Intraruminal infusion of propionate alters feeding behavior and decreases energy intake of lactating dairy cows. J Nutr 133: 1094-1099

Overton TR, Waldron MR 2004: Nutritional management of transition dairy cows: strategies to optimize metabolic health. J Dairy Sci 87: 105-119

Radojičić B, Šamanc H, Pejin I 2007: Concentrations of cortisol, insulin, glucose and lipids in the blood of calves at various ages. Acta Vet-Beograd 57: 191-198 
Reynolds CK, Aikman PC, Lupoli B, Humphries DJ, Beever DE 2003: Splanchnic metabolism of dairy cows during the transition from late gestation through early lactation. J Dairy Sci 86: 1201-1217

Silke S 1989: Testing the adrenaline function of newborn calves using the ACTH stimulation test (in German). Doctoral Dissertation, Hannover, $146 \mathrm{p}$.

Stamatović S, Šamanc H, Mandić L 1984: Contribution to investigation of glycemia in newborn calves. Veterinarski glasnik 38: 1039-1043 